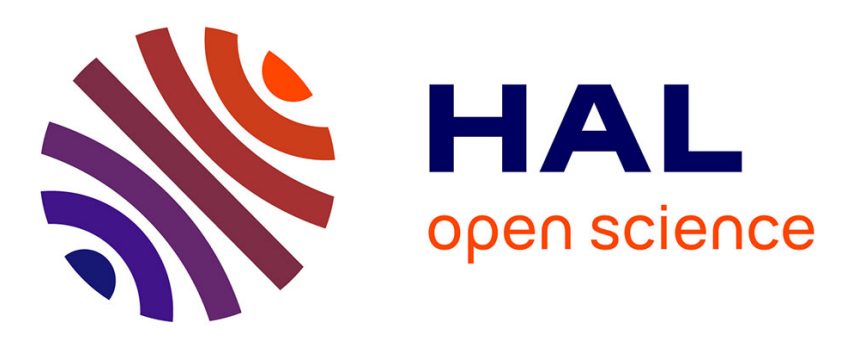

\title{
Mapping erosion risk and selecting sites for simple erosion control measures after a forest fire in Mediterranean France
}

Dennis Fox, W Berolo, Pierre Carrega, Frédéric Darboux

\section{- To cite this version:}

Dennis Fox, W Berolo, Pierre Carrega, Frédéric Darboux. Mapping erosion risk and selecting sites for simple erosion control measures after a forest fire in Mediterranean France. Earth Surface Processes and Landforms, 2006, 31, pp.606-621. 10.1002/esp.1346 . hal-02572238

\section{HAL Id: hal-02572238 \\ https://hal.science/hal-02572238}

Submitted on 6 Dec 2021

HAL is a multi-disciplinary open access archive for the deposit and dissemination of scientific research documents, whether they are published or not. The documents may come from teaching and research institutions in France or abroad, or from public or private research centers.
L'archive ouverte pluridisciplinaire HAL, est destinée au dépôt et à la diffusion de documents scientifiques de niveau recherche, publiés ou non, émanant des établissements d'enseignement et de recherche français ou étrangers, des laboratoires publics ou privés. 


\title{
Mapping erosion risk and selecting sites for simple erosion control measures after a forest fire in Mediterranean France
}

\author{
D. Fox, ${ }^{\prime *}$ W. Berolo,' P. Carrega' and F. Darboux ${ }^{2}$ \\ UMR 6012 Espace CNRS, Equipe GVE, Department of Geography, University of Nice Sophia Antipolis, BP 3209 06204, Nice cedex 3, \\ France \\ ${ }^{2}$ INRA Orléans - Science du Sol, Ave. de la Pomme de Pin, BP 20619, F-45I66 Olivet cedex, France
}

* Correspondence to:

D M Fox, UMR 6012

Espace CNRS, Equipe GVE,

Department of Geography,

University of Nice, Sophia

Antipolis, BP 320906204 ,

Nice cedex 3, France.

E-mail: fox@unice.fr
Received 7 December 2004:

Revised 20 June 2005;

Accepted 18 August 2005

\begin{abstract}
Major forest fires occur periodically in the Mediterranean environment. The impact of forest fires on soil erosion and runoff processes has been studied extensively, and it has been demonstrated that the first months after a fire represent a high risk period. Erosion control strategies must be established in the weeks following a forest fire to reduce fire impacts during the critical phase. Both dead and live vegetation techniques can be used to either reduce soil loss from slopes or trap sediments in streams before they enter the main channel: these include log erosion barriers, log debris dams and grass filter strips. The major challenge is defining where to position the measures quickly in a catchment where several thousand hectares have been burned. The method proposed here is based, firstly, on a simple soil erosion model that identifies critical erosion zones, and secondly, on a more detailed analysis of high risk slopes according to their potential impact on the main river channel, the value of the soil resource to be protected, the availability of pine logs, and accessibility to the site. Measurements of suspended sediment load in the main channel and tributaries confirmed that the erosion risk map was suitable for the purposes of the study. Many of the recommendations suggested were implemented and a study is underway to evaluate their effectiveness in reducing erosion and trapping sediments. Copyright () 2006 John Wiley \& Sons, Ltd.
\end{abstract}

Keywords: post-fire erosion; erosion control techniques; erosion control strategy; log erosion barriers; log debris dams; grass filter strips

\section{Introduction}

The Mediterranean climate is particularly conducive to large-scale forest fires. Mean annual precipitation is sufficient to support a dense mixture of oak, pine and other forest species, and the warm dry summer season makes both the live and accumulated biomass highly inflammable for at least two months of the year (Vallejo and Alloza, 1998; Pausas and Vallejo, 1999). The abandonment of traditional underbrush clearing practices combined with an increase in accidental and intentional fire ignitions has led to more frequent forest fires throughout much of the Mediterranean region (Moreno and Vallejo (1999) in Fernandez-Abascal et al., 2003). Changing climatic conditions are likely to increase the number of fires and area burned in coming years (Pausas, 2004). The impacts of a major forest fire on runoff and erosion are well known, and include greater peak flows and soil loss until the return of a vegetation cover. The first winter following a summer forest fire is the most vulnerable period, and runoff and erosion rates generally decrease rapidly afterwards (Soto and Díaz-Fierros, 1998; Vacca et al., 2000). It is therefore essential that runoff and erosion management strategies be implemented in the first weeks after a fire.

Elaborating an erosion reduction strategy after a forest fire is quite different from the usual erosion control contexts where soil loss is due mainly to agricultural practices and where a strategy can be elaborated over a period of months and put into place over a period of years. In this case, the techniques used and their spatial location must be decided upon urgently and in an administrative context where the sources of funding, funding channels and agency responsibilities are all evolving over a period of days to months. Local authorities need to act quickly with limited means while awaiting the transfer of more important resources, often months later. In such a context, log erosion barriers 
(LEBs) on slopes and log debris dams (LDDs) provide relatively quick and cheap erosion control practices that require little technical skill, machinery or time. These measures can be complemented by grass filter strips so that dead and live vegetation are combined to reduce erosion rates on critical slopes and to trap sediments in streams before they enter the main channel. One of the main challenges in installing these practices is deciding on the most effective locations.

The objective of this paper is to present a method used to define the location of LEBs, LDDs and grass filter strips in the weeks following a major forest fire in southeast France during the summer of 2003.

Several natural factors determine the impact of a fire on post-fire runoff and erosion rates; these include pre-fire vegetation, topography, slope aspect, fire severity, changes in soil properties, and post-fire rainfall (Walsh et al., 1992; Rubio et al., 1997; Inbar et al., 1998; Soto and Díaz-Fierros, 1998; Thomas et al., 2000; De Luis et al., 2003). Although many of these factors (such as slope or rainfall intensity) are common to all soil erosion contexts and need little explanation, the changes in soil erodibility brought about by the intense heat are particular to forest fire conditions. For this reason, these will be reviewed briefly before presenting the erosion control strategy.

\section{The impact of forest fires on soil erodibility}

The increase in runoff and soil erosion rates observed after a forest fire are due primarily to the destruction of the vegetation cover (Prosser and Williams, 1998; Wohlgemuth et al., 2001). However, the combustion of the standing vegetation and litter layer provokes several changes in soil properties. The study of low severity fires or traditional slash-andburn methods has confirmed some of the short-term benefits of forest fires on soil fertility ( $\mathrm{pH}$, nutrient status) and their influence on post-fire regrowth (Soto et al., 1995; Neary et al., 1999). However, the effects are not all beneficial since the combustion of the soil organic matter can also lead to lower cation exchange capacities, and high severity fires can lead to significant nutrient losses through volatilization and accelerated erosion (Martin et al., 1998; Neary et al., 1999; Thomas et al., 1999). Two further changes in soil characteristics - the development or enhancement of hydrophobicity and a decrease in aggregate stability - have a direct impact on soil erodibility (Andreu et al., 2001).

The formation of soil hydrophobicity, or water repellency, has been described extensively elsewhere (e.g. Wallis and Horne, 1992; DeBano, 2000a,b; Doerr et al., 2000; Huffman et al., 2001), so only a few aspects related directly to runoff generation and soil erosion will be considered here. Water repellency develops naturally in most Mediterranean forests (Doerr et al., 1998; Mataix-Solera and Doerr, 2004). During a forest fire, heat from the combustion vaporizes organic substances, some of which migrate downwards into the soil where they condense at cooler temperatures and coat mineral particles (DeBano, 2000a). After a forest fire, it is therefore common to find a thin layer of hydrophobic soil at the surface or within a depth of a few centimetres (DeBano, 2000a; Mataix-Solera and Doerr, 2004).

Although the effect of hydrophobicity on runoff and erosion has clearly been demonstrated at the plot scale, it has been difficult to demonstrate its importance for a catchment (Shakesby et al., 1993, 2000). One reason for this is the high spatial variability in hydrophobicity: at the catchment scale, preferential flow in decayed root channels, cracks, rodent burrows and hydrophilic patches may account for a large proportion of the infiltrated water (Imeson et al., 1992; Ferreira et al., 1997; Shakesby et al., 2000).

The impact of forest fires on soil aggregate stability is more ambiguous than for hydrophobicity. On the one hand, forest fires tend to produce greater water repellency in most forest soils, and this tends to reduce slaking, thereby increasing aggregate stability (Mataix-Solera and Doerr, 2004). On the other hand, aggregate stability is positively correlated with organic matter content, so the destruction of the organic compounds present in the soil tends to diminish aggregate stability (Cerdà et al., 1995; Giovannini et al., 2001). The net effect probably depends on initial organic matter content, soil texture, fire intensity, and the size range of aggregates being considered. Mataix-Solera and Doerr (2004) showed that finer sieve fractions $(<0.25 \mathrm{~mm})$ are more hydrophobic than larger ones $(>0.25 \mathrm{~mm})$, and that both hydrophobicity and aggregate stability are correlated with soil organic matter for different sieve fractions, but this question requires further research.

Soils on south-facing slopes tend to have both lower aggregate stability values and greater erosion rates than soils on north-facing slopes (Cerdà et al., 1995; Marqués and Mora, 1998; Andreu et al., 2001). Several reasons can explain this: south-facing slopes in the Mediterranean climate tend to have greater potential evapotranspiration rates leading to sparser vegetation cover and therefore thinner soils and lower soil organic matter contents. In addition, the drier conditions on south-facing slopes may make them more susceptible to forest fires with more frequent burns and exposure to soil erosion processes; finally, post-fire recovery on south-facing slopes is slower than on north-facing slopes (Cerdà et al., 1995; Pausas and Vallejo, 1999), so erosion processes continue for longer.

\section{Description of vegetation erosion control techniques for post-fire protection}

Post-fire vegetation strategies can take two forms: urgent intervention to protect steep slopes, and long-term plantation 
to improve resilience and maturity of the ecosystem (Vallejo and Alloza, 1998; Espelta et al., 2003). In this paper, only the former is taken into consideration since the greatest risk of erosion is in the first year and erosion rate tends to approach pre-fire levels after the second year, though differences may persist for up to five or six years (Walsh et al., 1995; Martin et al., 1998; Vacca et al., 2000; Andreu et al., 2001). Soil loss decreases as easily detached and transported sediments are removed and vegetation re-establishes itself (Soto and Díaz-Fierros, 1998). The trend depends not only on vegetation regrowth but on precipitation distribution, and observations have been made of greater erosion in the second year than the first because of much greater rainfall (Shakesby et al., 1996). In the context of this study, three erosion control techniques were retained: LEBs, LDDs and grass filter strips. Straw mulches have been shown to be effective (Robichaud, 2004), but practical reasons, including the lack of a local supply of straw, made this solution unfeasible.

LEBs consist of cutting and laying fire-killed trees on the ground parallel to slope contours (Figure 1). Laid across the slope, the logs slow runoff and trap sediments. The technique is widely used as a post-fire management strategy, but few data are available on the efficiency of the LEBs, measured as a quantity of sediment trapped per number of logs per hectare. Wohlgemuth et al. (2001) attempted to quantify the impact of LEBs on sediment delivery, and the evidence suggests that LEBs are more efficient in trapping sediments than reducing runoff. A study conducted in Greece showed that LEBs were effective in trapping sediments on steep slopes (35-55 per cent) but not on low (10-20 per cent) or intermediate (20-35 per cent) slopes (Gagari et al., 2001). Marqués and Mora (1998) reported that branches used to build dykes to retain soil on slopes did not stop rill formation and some were destroyed by heavy rains. Considerable attention must therefore be paid to log size and placement on the slope, in addition to LEB density.

LDDs are log barriers placed across a stream and held in place with vertical log posts, or by placing the horizontal logs against the upstream side of tree stumps (Figure 2). Branches can be used to fill in spaces between logs and the voids are further clogged by leaves and floating debris carried during stream runoff. LDDs vary from LEBs in that the logs are stacked across the width of a stream while the LEBs are installed on the slopes. LEBs therefore contribute to maintaining the soil on the slope, while LDDs trap the sediments in the tributary channels.

The beneficial effect of grass strips in filtering nutrients, pesticides and sediments transported in runoff has been proven in an agricultural context (Hayes et al., 1984; Vought et al., 1995; Ligdi and Morgan, 1995; Tadesse and Morgan, 1996; Munoz-Carpena et al., 1999; Deletic, 2001). Reduction rates vary from about 50 per cent to 95 per cent depending on vegetation type, strip width, upslope inclination and area, and rainfall characteristics. However, the use of grass strips in forests is more controversial since sown grasses may compete with local species and interfere with natural regeneration (Valleho and Alloza, 1998; Pinaya et al., 2000). Despite this, plot trials have demonstrated that sown plots establish a protective vegetation cover more quickly than natural regrowth, and that erosion rates are lower on sown plots after an initial period of growth (Pinaya et al., 2000). Seeding has also been combined with a straw mulch where both the grass and mulch contribute to reduce erosion (Vallejo and Alloza, 1998). Therefore,

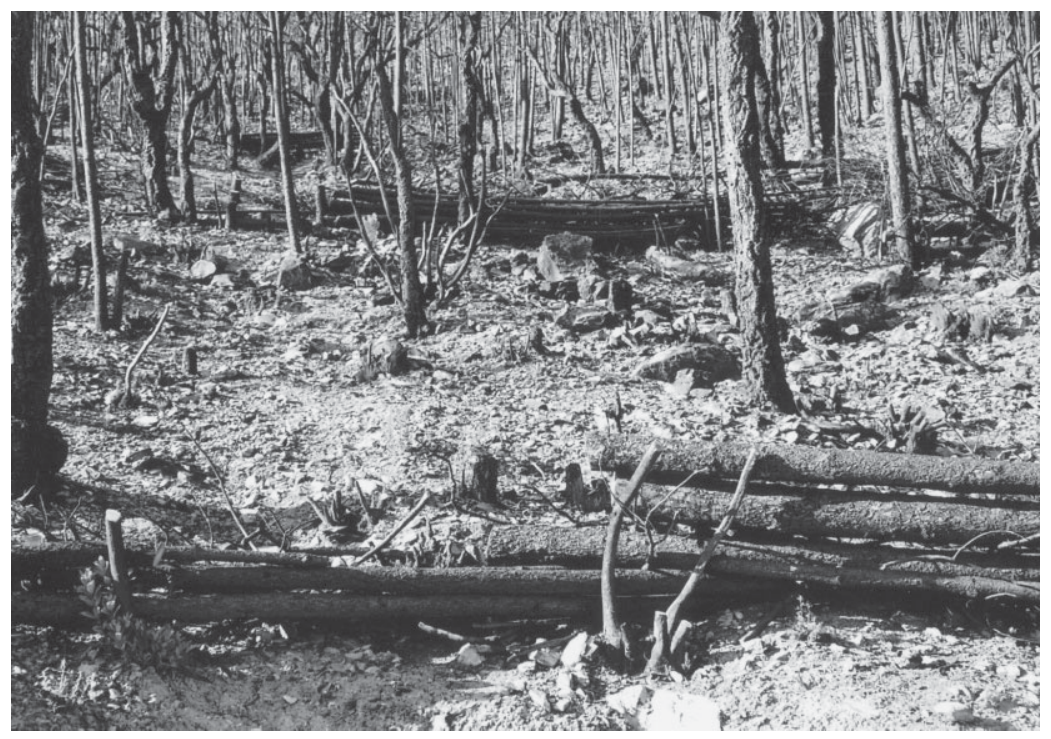

Figure I. Log erosion barriers (LEBs) among standing vegetation. 


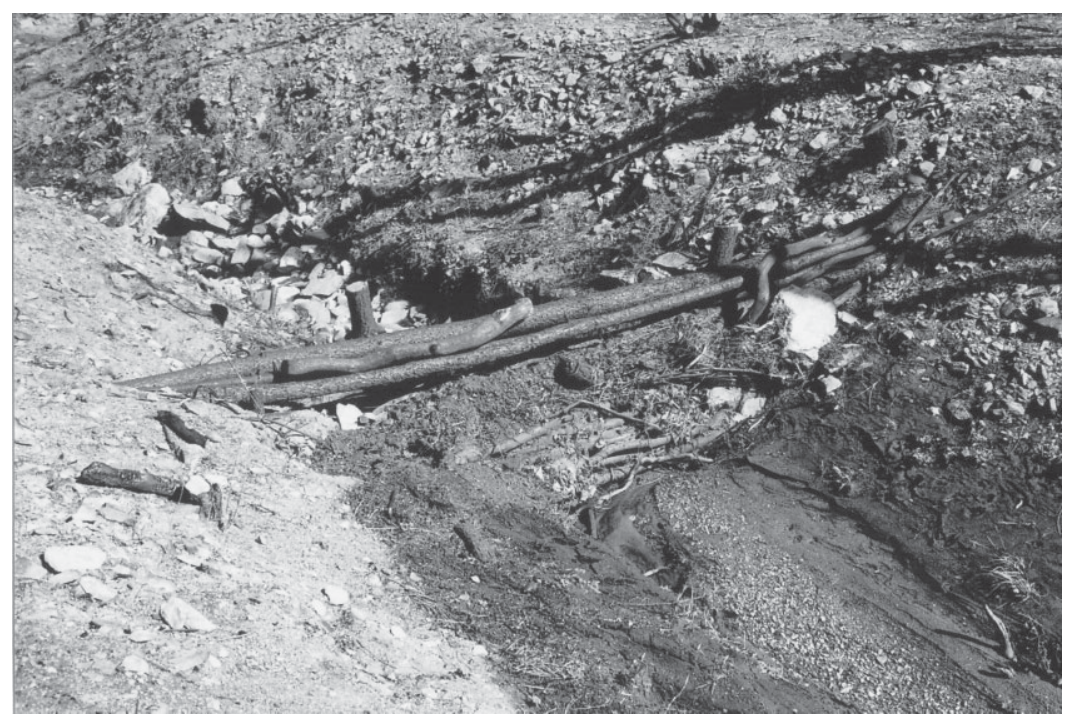

Figure 2. Log debris dam (LDD) showing trapped sediment and debris upstream of dam.

although widespread aerial seeding may be accompanied by low growth rates and poor cover, concentrating seeding in localized dense grass strips can provide good protective cover and is not a major obstacle to natural revegetation (Vallejo and Alloza, 1998).

\section{Site description}

The study area is located in southeast France in the Massif des Maures near St Tropez; the approximate centre of the burnt area is $43^{\circ} 16^{\prime} \mathrm{N}, 6^{\circ} 28^{\prime} \mathrm{E}$. The Giscle catchment has a surface area of about $234 \mathrm{~km}^{2}$ and is composed of two major topographical features. The lower portion of the catchment (roughly 25 per cent of the total area) is an alluvial plain occupied by vineyards and urban development. The upper portion (about 75 per cent) of the catchment has forested hilly terrain dominated by a mixture of Mediterranean oak and pine species. A major forest fire which occurred at the end of August 2003, burned more than 2000 ha located at the head of the Giscle river and a few of its tributaries. Local authorities were therefore concerned about the impact of increased runoff on the urbanized areas downstream, as well as the possible increase in sediment load entering the port.

Annual precipitation is about $950 \mathrm{~mm}$, with rainy seasons in the autumn and spring. The hilly forested zone is underlain by metamorphic gneiss and schists, and the soils are classified as Rankers in the FAO classification. Soil textures for the $<2 \mathrm{~mm}$ fraction are typically about 75 per cent sand, 10 per cent silt and 15 per cent clay. Mean weight diameter (MWD), measured using the method of Le Bissonnais (1996), for soils in the valley bottom is $3 \cdot 28 \mathrm{~mm}$ $($ s.d. $=0 \cdot 07)$, classifying these soils as highly erodible.

\section{Method}

Selecting sites for installing the erosion control measures was carried out in two stages: in the first, a simple soil erosion risk map was obtained from the mapping of a number of factors described above. The map was useful in identifying high risk areas and determining subcatchments that might represent a particular risk for the main channel. However, soil erosion risk is only one of several factors that determine where to install erosion control measures, and a soil erosion control strategy cannot be based on erosion risk alone. In the second stage, the potential sites were evaluated according to the following criteria (described in more detail below): soil erosion risk, impact on main channel, value of resource to be protected, availability of suitable logs for the LEBs and LDDs, and accessibility to the sites. Each high risk erosion zone presented its own particular combination of benefits to be considered separately.

\section{Mapping soil erosion risk}

Since undisturbed forests typically have very low soil erosion rates, most soil erosion models were developed for agricultural contexts and were not suitable for the burned forest site. Measuring soil erosion and elaborating a 
regression model were also out of the question due to the lack of time. After an initial survey of the digital data available, the dominant factors affecting soil erosion (described below) were mapped and combined to create an erosion map. The multiplicative method is described below after a presentation of the factors. In the field, each layer was mapped on a 1:25 000 topographic map; some areas of the burned upper catchment were inaccessible except via footpaths, much of the burned catchment was accessible only via unmade roads (fire prevention access roads and private lanes), and only the lower portion of the catchment could be accessed by car. Most of the mapping was therefore carried out by cycling throughout the catchment and combining direct on-site observations with panoramic views from viewpoints using binoculars for remote sites. Roughly 2000 ha had to be mapped in a few days, so each factor was attributed a number of qualitative classes that could be estimated quickly without time-consuming measurements. The methods used are outlined below after a description of the soil erosion factors.

\section{Soil erosion factors}

Slope. The importance of slope inclination for soil erosion is well known, and a digital elevation model (DEM) of the catchment with a $50 \mathrm{~m}$ grid was already available, but the resolution quickly revealed itself to be insufficient, so a $25 \mathrm{~m}$ DEM was ordered.

Pre-fire vegetation. Pre-fire density was estimated from the standing charred trunks, and three categories were included: bare, low density, and medium density. Rock outcrops were devoid of any vegetation and the distinction between low and medium density was based mainly upon the ease of walking through the charred forest. In addition to the mulch effect provided by fallen pine needles described above (Shakesby et al., 1993, 1994), standing dead vegetation may favour infiltration (near stems and in burned roots) and slow runoff velocity, so the net expected effect is lower erosion where vegetation stands are more dense.

Fire severity. This is a major factor influencing runoff and soil erosion rates (Robichaud and Waldrop (1994) cited in Letey, 2001; Rubio et al., 1997; Prosser and Williams, 1998). Two severity categories were included: variable and intense. Variable severity sites were designated as areas where either the fire had passed quickly and charred the trunks and underbrush but left the crown more or less intact, or where the intense combustion of the standing vegetation was confined to a small area (dozens of square metres). In intense severity zones, the fire had consumed the underbrush and crown entirely over an extensive area.

Soil erodibility. Soil depth and stoniness distribution within the catchment are controlled by slope inclination, position within the catena, and aspect. Thin stony soils were generally found on steep slopes, convexities and southfacing slopes, while deeper, less stony soils were found on gentler slopes, concavities and north-facing slopes. Three classes were defined: thin and stony, of intermediate depth and stoniness, and deep with few stones. A soil corer was used along a dozen slope transects and thin soils were designated as those that had depths of $<20 \mathrm{~cm}$. A soil was considered deep if it was $>50 \mathrm{~cm}$ in depth.

\section{Ascribing coefficients and combining the soil erosion factors}

Mapping the soil erosion risk was based on the multiplication of coefficients (Equation 1) ascribed to the soil erosion factors summarized in Table I.

$$
\text { Erosion Index }=\text { Slope } \times \text { Vegetation density } \times \text { Fire severity } \times \text { Soil erodibility }
$$

Table I. Coefficients ascribed to the four soil erosion factors used to estimate erosion risk: slope, pre-fire vegetation density, fire severity, and soil erodibility

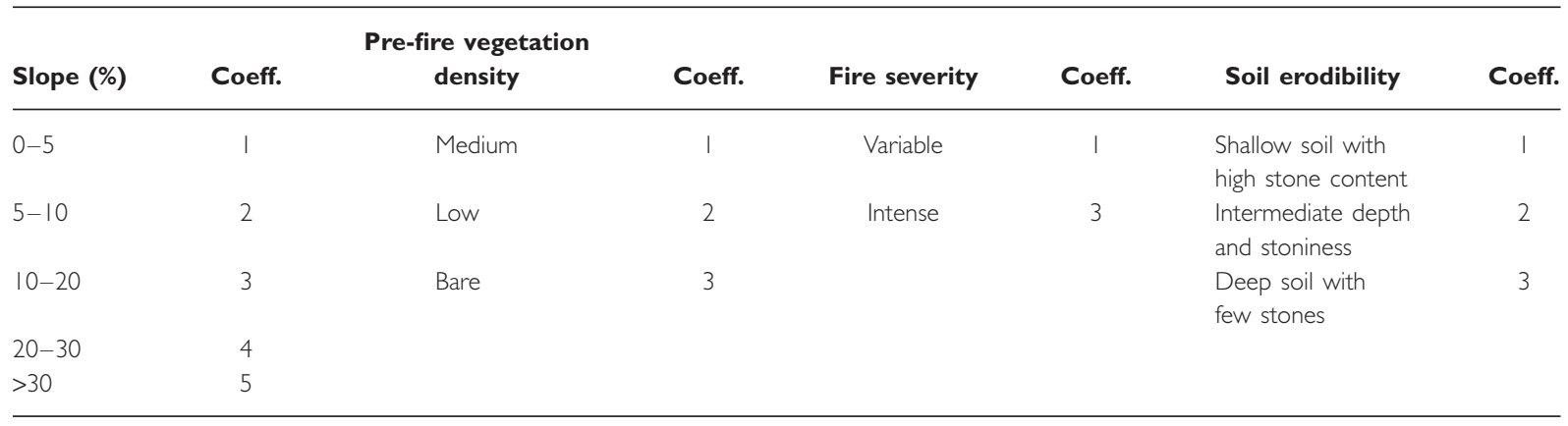


Table II. A brief description of the typical environments observed in the catchment for a range of erosion risk values

\begin{tabular}{|c|c|c|c|}
\hline Class & Erosion value & Area $\left(\mathrm{km}^{2}(\%)\right)$ & Summary description \\
\hline Low & $\leq 5$ & $3 \cdot 3(16)$ & $\begin{array}{l}\text { Valley bottoms with gentle slopes, low severity fire, } \\
\text { dense pre-fire vegetation and deep soils. Included are also some } \\
\text { flat topslope sections where soils are stonier and shallower. }\end{array}$ \\
\hline Intermediate & $6-15$ & $8 \cdot 3(40)$ & $\begin{array}{l}\text { Convexities and concavities upslope and downslope, respectively, } \\
\text { of major linear slope sections. These areas have gentler slopes } \\
\text { than the linear sections and are frequently found along the limits of } \\
\text { the pre-fire vegetation and fire serverity classes. }\end{array}$ \\
\hline High & $16-26$ & $6.5(31)$ & $\begin{array}{l}\text { Steep slopes with bare or low pre-fire vegetation densities } \\
\text { in the severely burned area dominate. One significant exception is the } \\
\text { north-facing slope located south of the main Giscle channel. In this area, } \\
\text { pre-fire vegetation density and soil depth are greater than elsewhere in } \\
\text { the high erosion risk class, but the steep slopes make it vulnerable } \\
\text { to erosion. }\end{array}$ \\
\hline Very high & $\geq 27$ & $2 \cdot 7(13)$ & $\begin{array}{l}\text { Severe fire conditions in low density pre-fire vegetation (with patches } \\
\text { of bare slope) on very steep slopes. }\end{array}$ \\
\hline
\end{tabular}

For each factor, a raster layer with a $25 \mathrm{~m}$ cell size was created using geographic information software. Each cell within the layer was assigned a coefficient (Table I) and the layers multiplied (Equation 1) to provide a theoretical range of values of from 1 to 135 . In the absence of a suitable, functional and readily available soil erosion model, values for the coefficients were attributed arbitrarily according to personal experience and field observations. Estimating coefficients for slope, vegetation and fire severity was relatively straightforward. The soil erodibility coefficients were more problematic: shallow stony soils generate more runoff but surface material is less mobile due to the high stoniness and, in many cases, the bare bedrock. Deep soils with fewer stones may have higher infiltration rates, but they are more erodible, particularly with respect to the weak aggregate stability and possible presence of hydrophobicity. It was therefore decided to increase the value of the coefficient with decreasing stone content, as can be seen in Table I.

\section{Partial validation of the soil erosion risk map}

Once the soil erosion risk map was completed, the catchment was divided into subcatchments and the percentage area in the high and very high risk categories (Table II) was calculated for each subcatchment. On 2 December 2003, a rainfall event generated significant runoff in the catchment: peak rainfall intensity values were not available but roughly $35 \mathrm{~mm}$ fell in the morning, and about $35 \mathrm{~mm}$ fell in the preceding five days (measured at about $5 \mathrm{~km}$ from the fire site). Runoff samples from most of the major streams were obtained manually by plunging a $0 \cdot 5$-litre bottle into the stream during the storm. Replicate suspended sediment samples from the main channel and selected tributaries were collected within a period of about $10 \mathrm{~min}$ so rainfall/runoff conditions were considered comparable. The amount of suspended sediment transported through the channel depends on both sediment concentration and discharge, but the timing imposed by sampling simultaneously and the difficult field conditions made it impossible to measure discharge accurately. Therefore, only suspended sediment concentrations were measured. An order of magnitude based on visual estimates would give discharges of about $10 \mathrm{~m}^{3} \mathrm{~s}^{-1}$ for the main channel and about 20-30 per cent of that value for the tributaries. It was therefore possible to compare the stream suspended sediment load to the percentage of the catchment in the high and very high risk categories. A stream draining a vineyard subcatchment and an unburned forest area were sampled for comparison.

\section{Selecting the sites for the LEBs, LSDs and grass strips}

Site selection depends on the objectives to be attained and these can vary from one location to another. In this catchment, a number of concerns were evoked by the local authorities: increase in peak flows with greater risk of flooding, greater sedimentation in the river channel and port, environmental impacts of soil loss on the slopes, decrease in the quantity of water percolating to the groundwater table (50 per cent of drinking water comes from groundwater which is replenished by infiltration in the forested zone). Among these, only two could be addressed seriously using the vegetative techniques, and these were reducing the amount of sediment entering the main channel and reducing the soil loss from slopes in selected areas. 
The erosion risk map was used to identify high risk sites, but each site presented its own set of advantages and disadvantages; the order in which these were evaluated generally corresponded to that of the factors listed below.

(1) Identification of the main sediment-contributing areas based on the erosion risk map.

(2) Determination of their impact on the main channel during an erosive event: this depends mainly on the probability that the sediments will not be deposited before reaching the main channel, so characteristics of the slope as well as the channels through which the sediments move were taken into consideration.

(3) The value of the soil resource to be protected: the deeper, less degraded soils were given priority over the very shallow stony soils.

(4) Availability of pine trees for the LEBs and LDDs: pine and mixed pine/oak stands were mapped since these were the only sites where the dead vegetation techniques could be used. Cork oak (Quercus suber) has a high survival rate due to the thermal insulation of the thick cork, and the mature trees that had not been harvested for their cork (found only along the roadsides) were expected to recover quickly (Pausas, 1997; Pausas and Vallejo, 1999; Barberis et al., 2003).

(5) Accessibility to the sites: some areas of the burned catchment were inaccessible and were ignored from the beginning.

\section{Results}

\section{Distribution of the soil erosion factors}

Figures 3 to 6 show the distribution of the four soil erosion factors in the catchment. More than 30 per cent of the slopes in the study area have an inclination greater than 20 per cent (Figure 3), showing the natural vulnerability of the zone to erosion processes. In addition, many of the steeper slopes were those most affected by the fire (Figure 4). Typically, pre-fire vegetation densities (Figure 5) were low on convexities or south-facing steep slopes with shallow

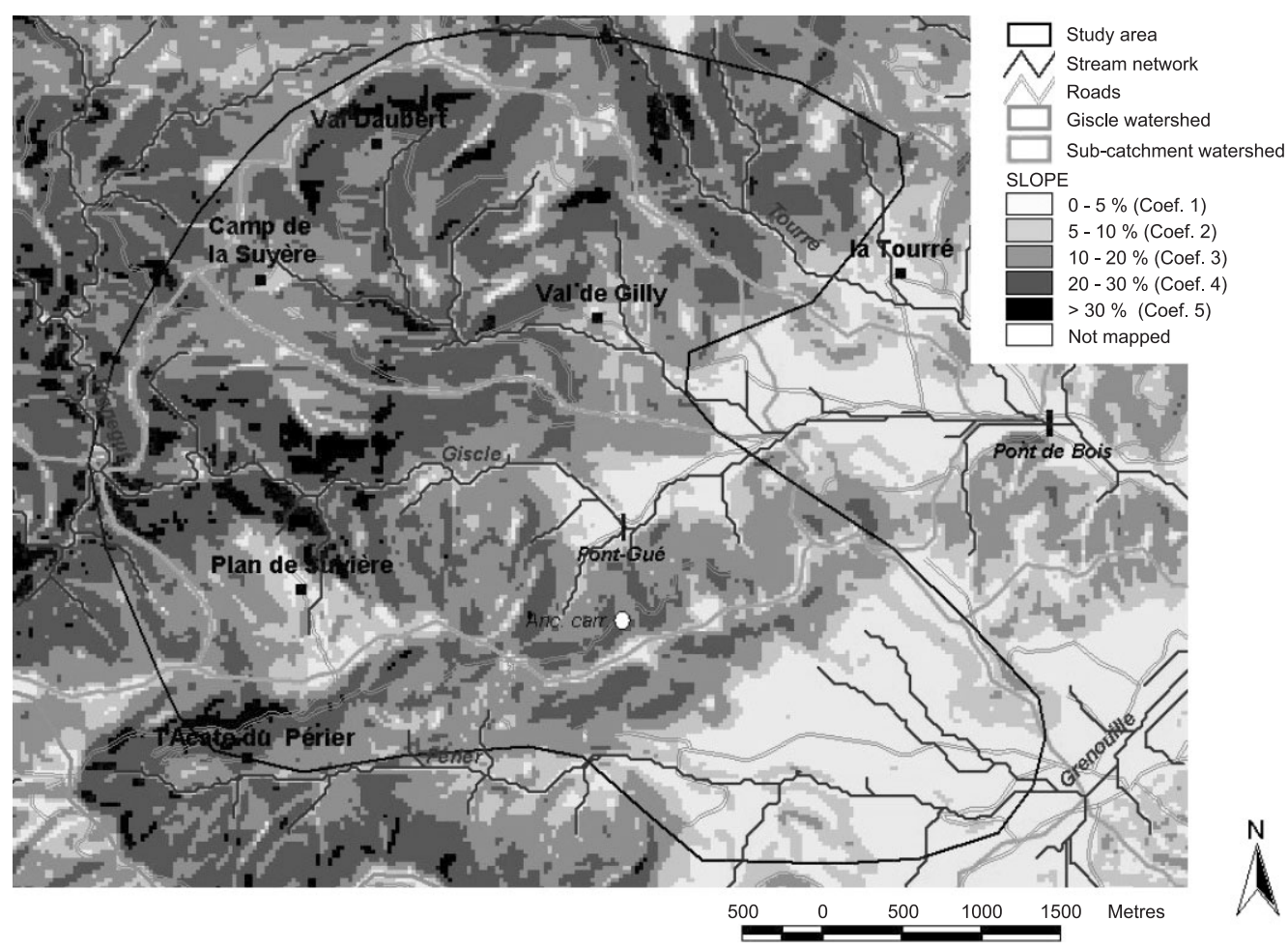

Figure 3. Map showing the distribution of slope classes and ascribed coefficients in the study area. 


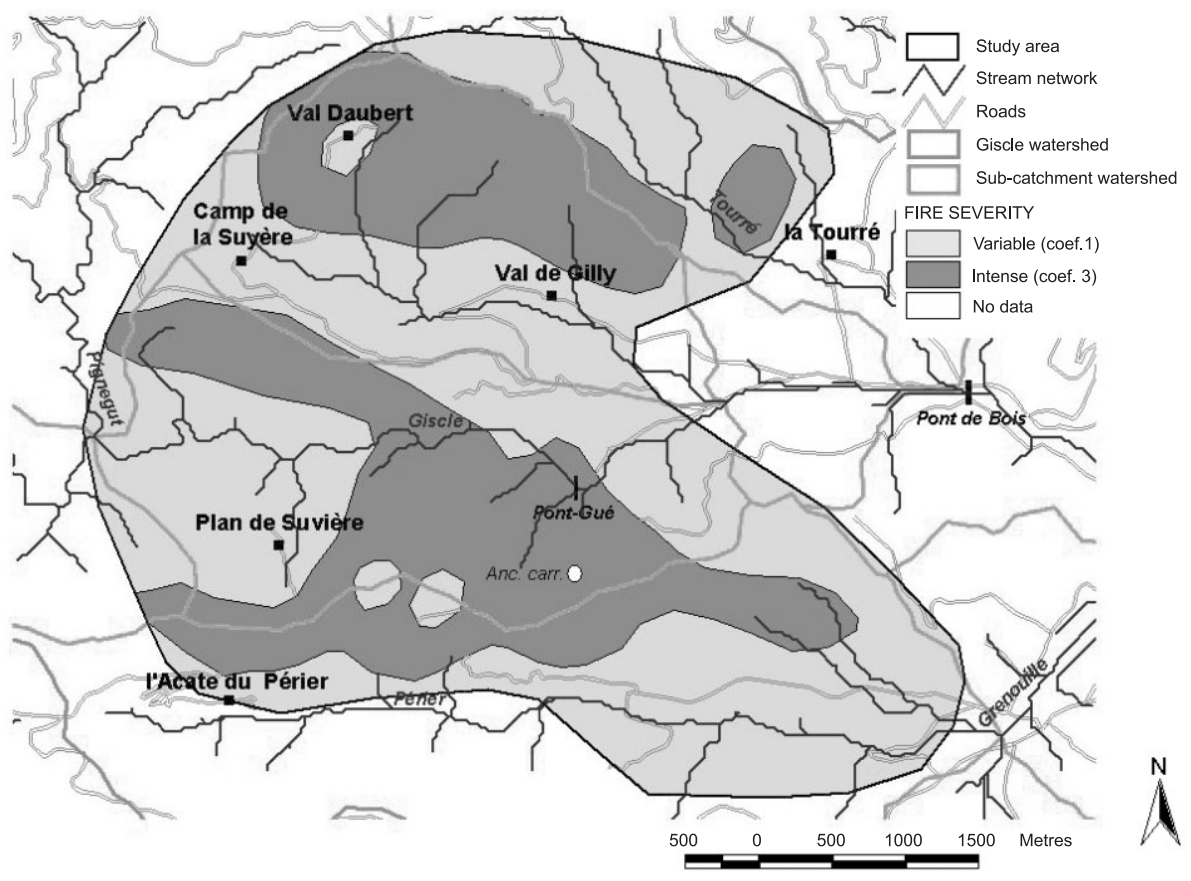

Figure 4. Map showing the distribution of fire severity and ascribed coefficients in the study area.

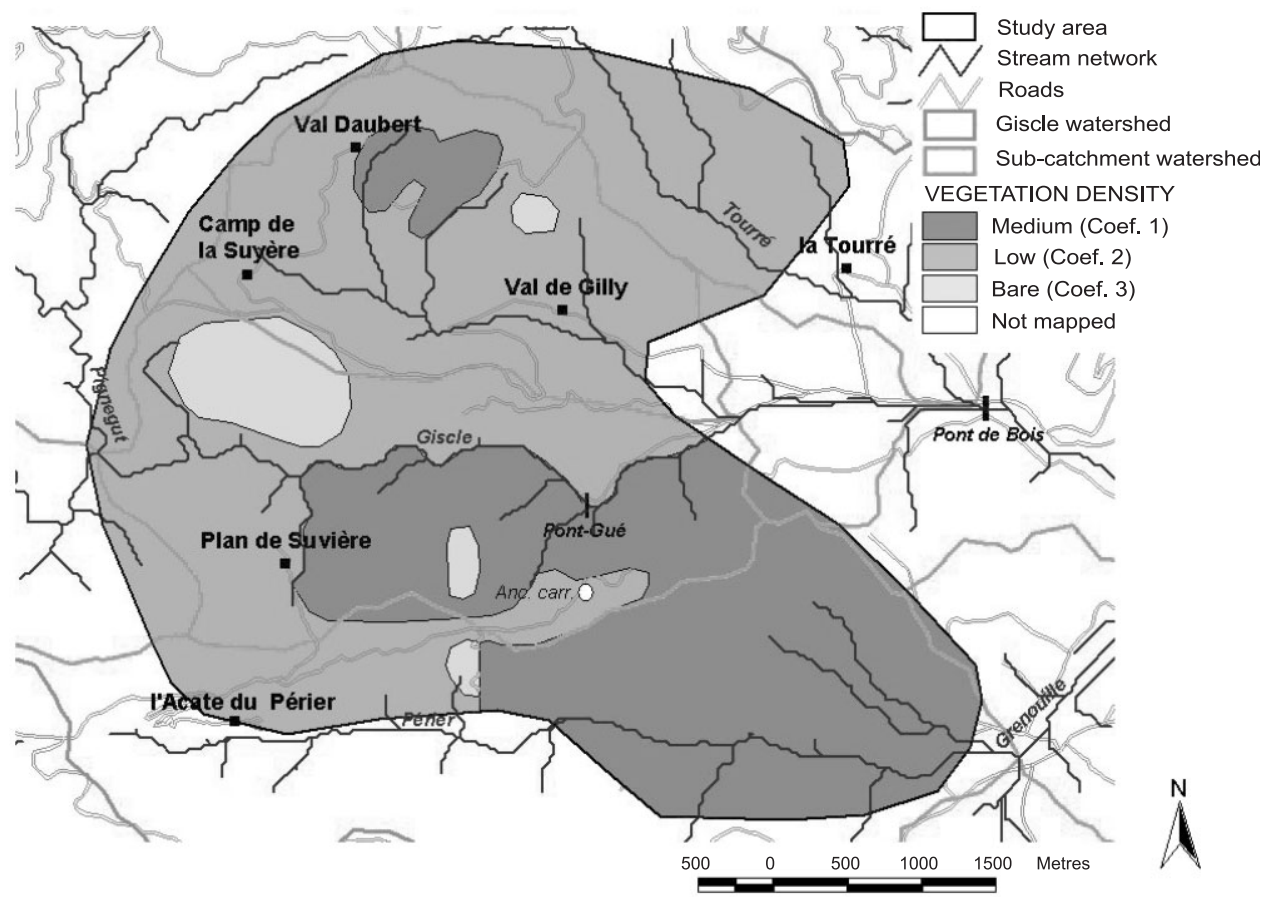

Figure 5. Map showing estimated pre-fire vegetation density and ascribed coefficients in the study area. 


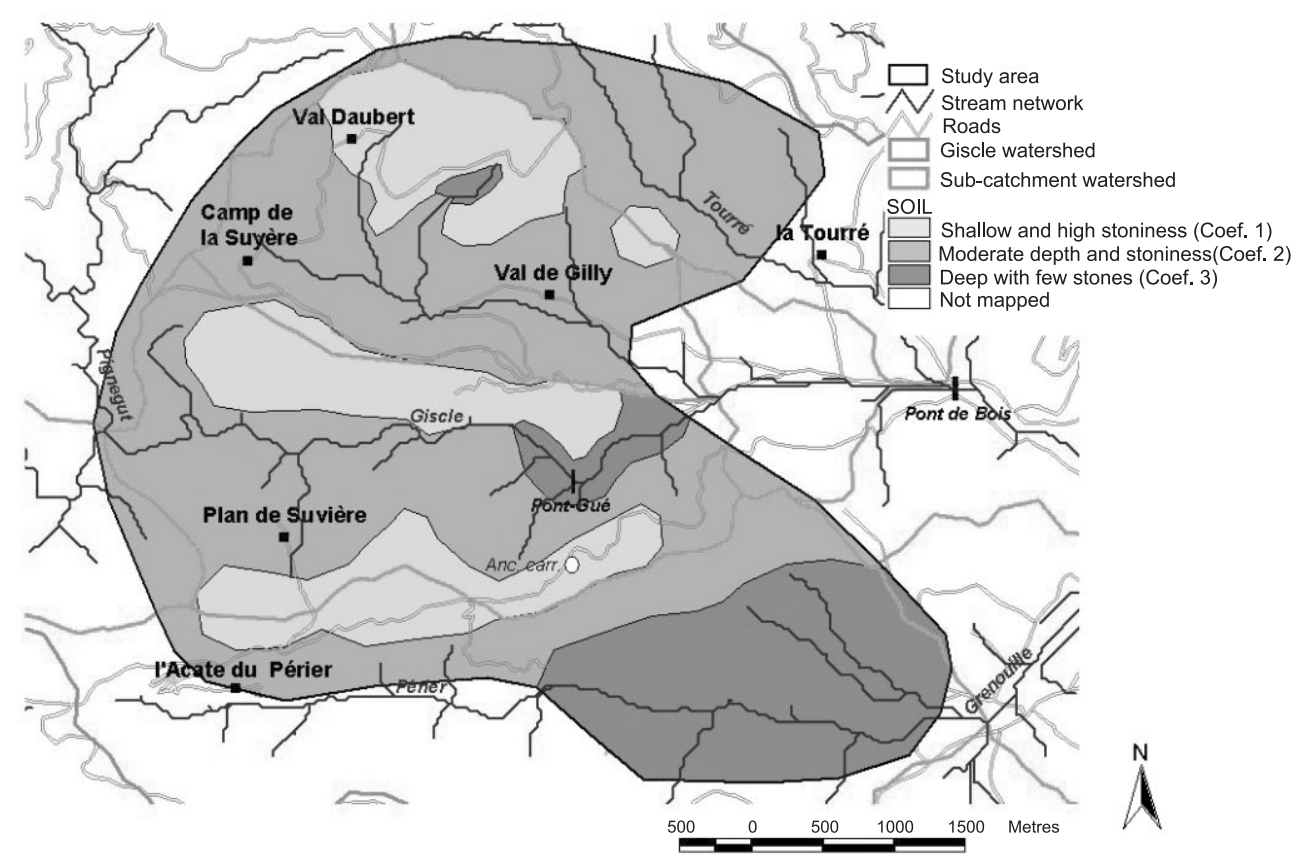

Figure 6. Map showing the distribution of soil characteristics and ascribed coefficients in the study area.

stony soils (Figure 6). Conversely, deeper soils with a denser pre-fire vegetation cover tend to be concentrated in the southeast corner of the map where slopes are gentle.

\section{The soil erosion risk map}

Values resulting from the multiplication of the factors ranged from 1 to 90 , and they were subdivided into soil erosion classes according to breaks between peaks in the histogram distribution. Values for each class are shown in Table II, and the results are shown in Figure 7. Each class tends to correspond to a typical environment (Table II).

As stated above, the erosion model used is extremely simple and the subjective definition of the coefficients is open to some debate, but the objective was to provide a quick spatial representation of general trends and not a quantitative estimate of soil loss, so it is unlikely that a more time-consuming modelling approach would have significantly altered the spatial distribution of the erosion classes identified. The authors had been working in the catchment for three years prior to the fire, and soil erosion in the vineyards had been mapped using both the Revised Universal Soil Loss Equation (RUSLE) and a regression equation based on measurements carried out in a reference area. Neither of these models, designed for agricultural contexts, could be applied to burned forest sites, and the data requirements for more complex deterministic models were unrealistic within the timeframe allowed for the post-fire management proposals.

\section{Partial model validation}

Significant runoff occurred during the storm of 2 December 2003 (Figure 8). Stream discharge samples (two replicates) were collected for three of the four main subcatchments. Sampling locations are shown in Figure 7: Tourré (1), Gilli (2), Giscle (3) (sampled upstream of other tributaries). The Périer in the southern part of the catchment could not be sampled in similar rainfall/runoff conditions, so it was not analysed. In addition, samples for the burned northfacing slope draining into the Giscle main channel (4), a vineyard (5) and an unburned forest (off the map) were collected for comparison purposes.

For each of the three subcatchments sampled and the burned north-facing slope, stream suspended sediment concentration was plotted against the sum of the percentage area in the high and very high risk erosion classes (Figure 9). The numbers in Figure 9 correspond to sampling locations in Figure 7. Sediment concentration values represent the means of two samples. Differences in concentration between samples were never greater than 10 per cent except for 


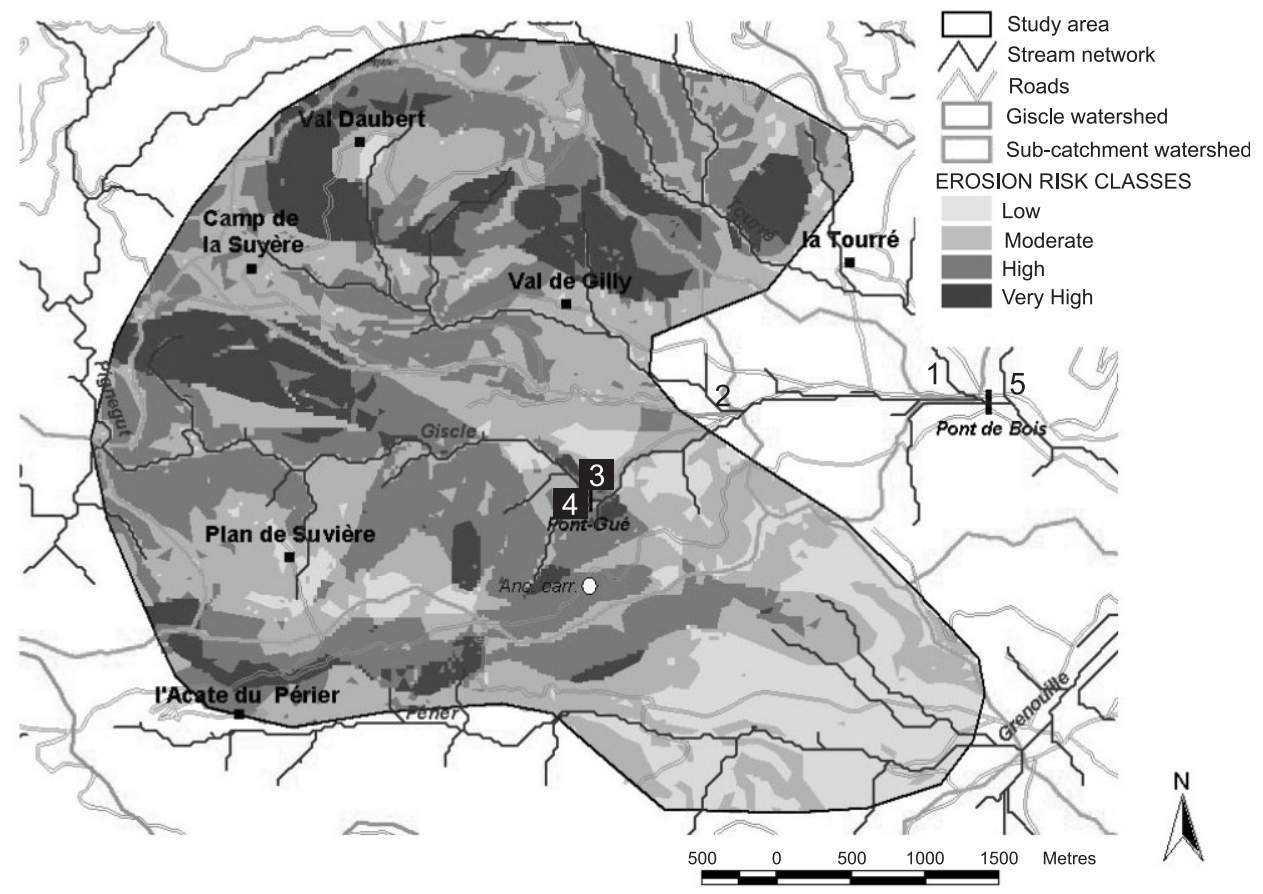

Figure 7. Soil erosion risk map showing the erosion risk categories and sites (numbered from one to four) for the suspended sediment samples used in the partial validation.

the Gilly, for which it was 31 per cent. Although there are only four points, there is a general trend for the sediment concentration to increase with increasing area in the high and very high erosion classes. The exception is the Giscle (sample 3) which is located immediately downstream of a long straight section with natural sediment deposition. Therefore, the low suspended sediment concentration of the Giscle was attributed to natural deposition in the stream bed upstream of the sampling area. Sediment concentrations for the vineyard (5) and unburned forest were $1.64 \mathrm{~g} \mathrm{l}^{-1}$ and $0 \mathrm{~g} \mathrm{l}^{-1}$, respectively.

\section{Locating the LEBs, LDDs and grass strips}

Selecting potential sites for installing erosion control measures was based on the erosion risk map (Figure 7), and these corresponded to zones where there was a concentration of high and very high risk classes (Table II). As shown in Figure 10, six sites were identified for field evaluation; these are ordered alphabetically (A-F) according to subcatchment, starting with the main Giscle channel. However, as noted above, a soil erosion risk map is not a soil conservation map. High erosion risk areas are not necessarily suitable for installing erosion control measures, and some of these are suitable for only certain types of measures. Therefore, once the high risk areas were identified, the second stage was to evaluate the following: potential risk to the main river channel, value of soil resource to be protected, and suitability for installing LEBs, LDDs and grass strips. Site suitability depended on accessibility, an estimate of the impact the measure would have on attaining the specified objective (maintaining sediments on the slope with the LEBs and grass strips or trapping sediments before they enter the channel with the LDDs), and the presence of pine logs for the LEBs and LDDs. Each of the major potential sites identified by the erosion risk map is described below with the recommendations.

\section{Slope sections A and B (Giscle)}

These slopes were addressed first since slope runoff enters the main channel directly. In addition, the north-facing slope A had relatively deep soils (Figure 6), a high potential erosion rate (Figure 7), and high sediment concentrations during the December rainfall event (Figure 9). This slope section therefore had an immediate impact on the main channel and soils worth protecting. The site was easily accessible. Three measures were suggested: (1) it was proposed 

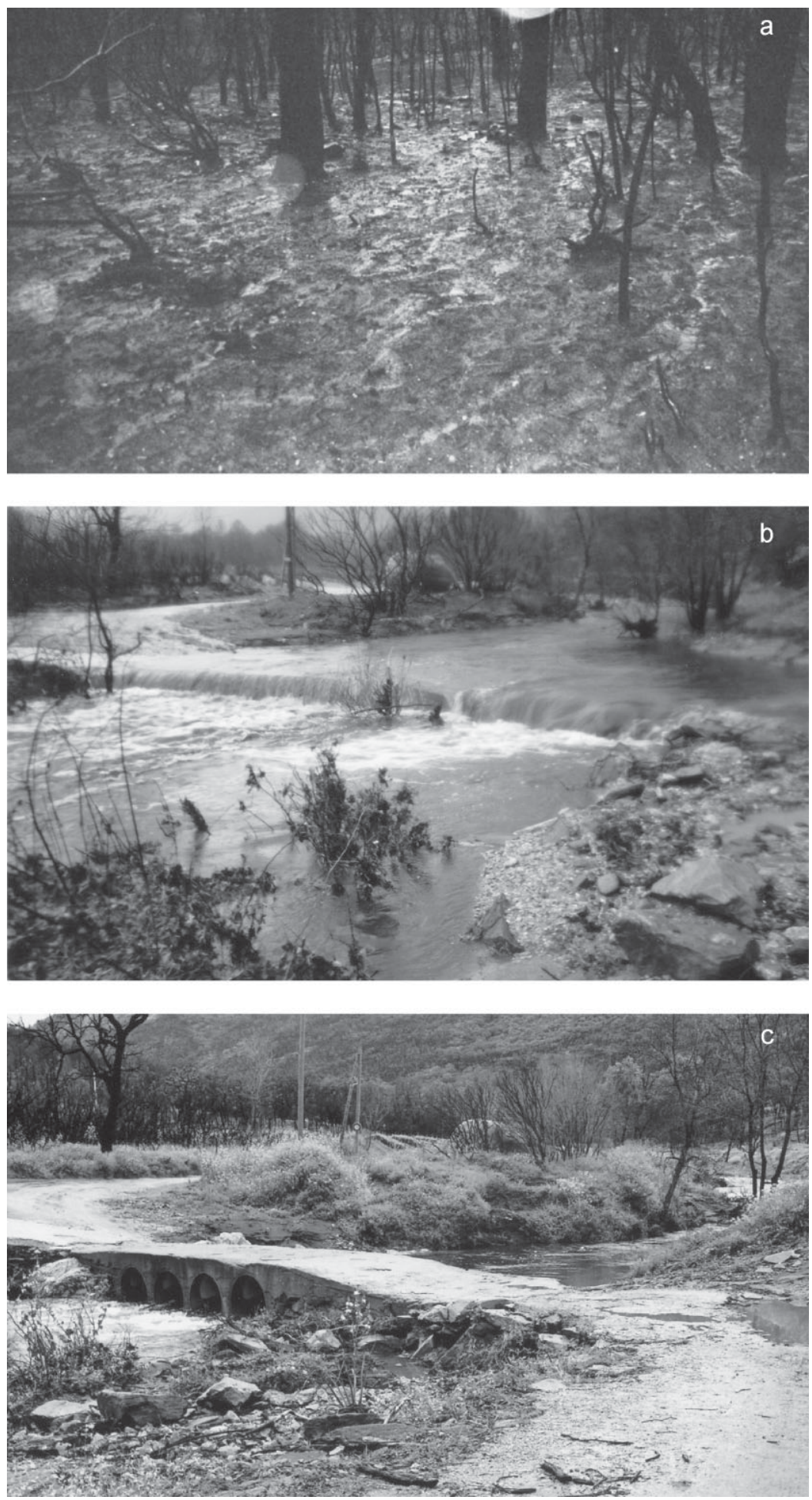

Figure 8. (a) Runoff observed in the burnt forest and (b) runoff flowing over a low bridge (Pont Gué) during the storm of 2 December 2003. (c) The same bridge as in (b) (Pont Gué) at normal discharge. 


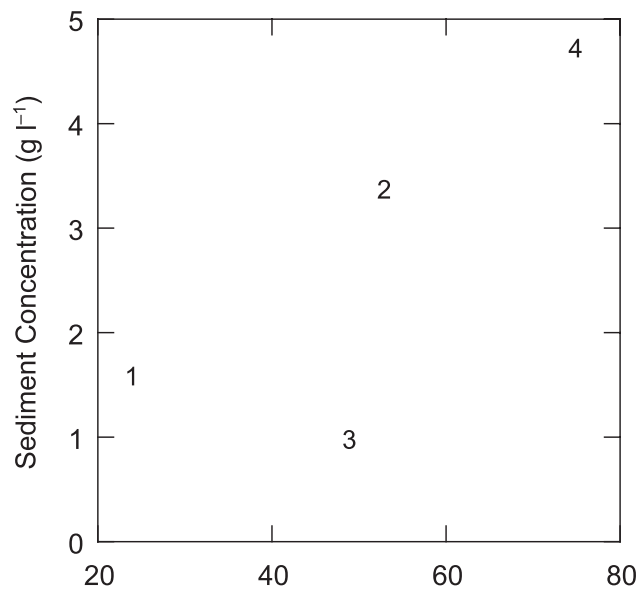

1 Tourré

2 Gilly

3 Giscle

$20 \quad 40 \quad 60 \quad 80$

4 Ephemeral stream

Proportion of area defined as high or very high erosion risk

Figure 9. Relationship between sediment concentrations in storm runoff and proportion of area (\%) defined as high or very high erosion risk (numbers refer to site locations shown in Figure 7).

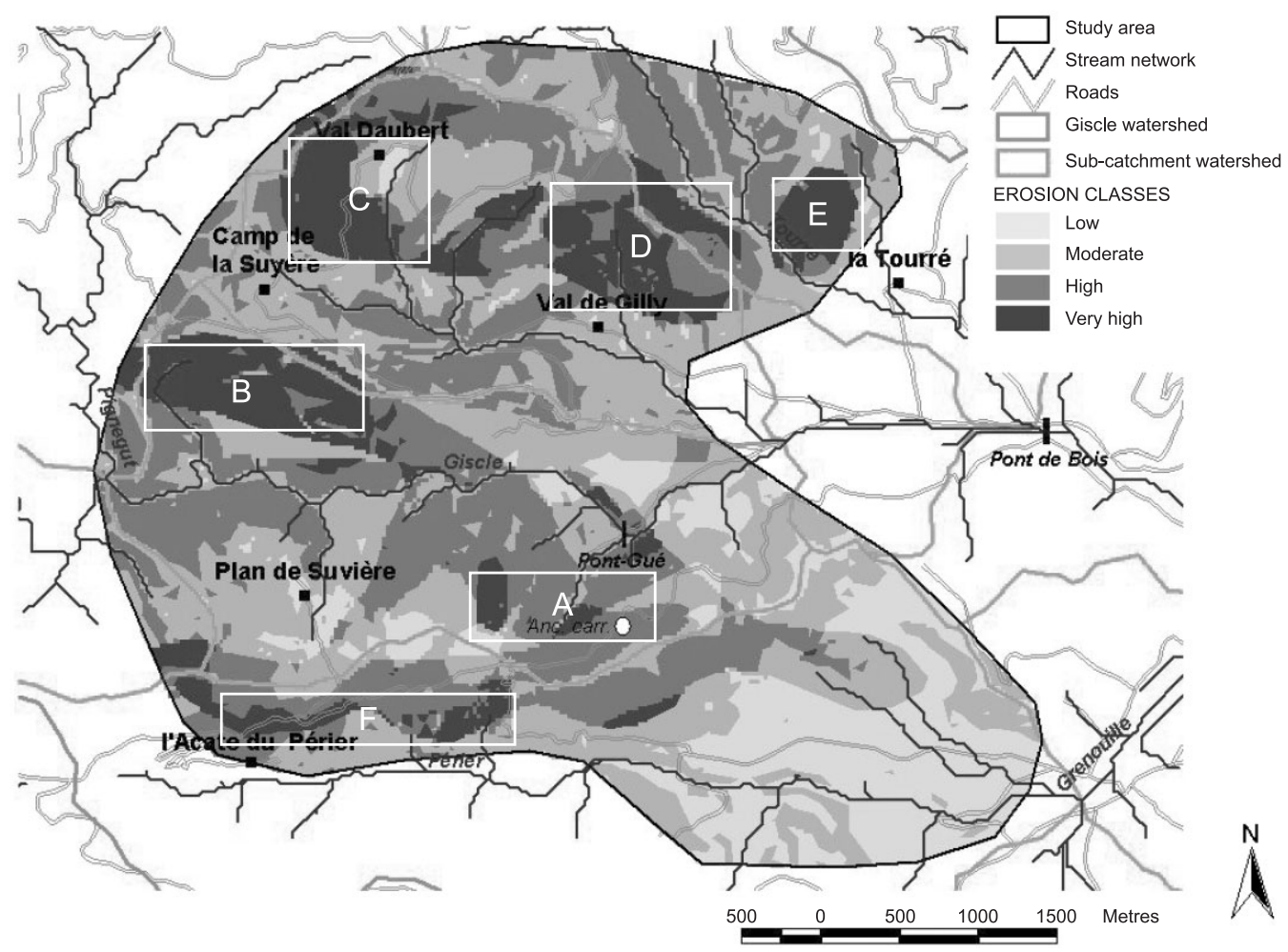

Figure 10. Location of priority zones $(\mathrm{A}-\mathrm{F})$ to be assessed for the installation of erosion control methods.

that a $40 \mathrm{~m}$ grass strip be planted between an upper road and lower river channel to divide the slope equally; (2) it was suggested that a series of LDDs be set up in the ephemeral streams; and (3) LEBs were to be put in place in the pine stands.

Slope section B was different: soils were thin and stony (Figure 6) on this south-facing slope, there were no avalaible logs from nearby stands of pine, and the site was less accessible than slope section A. For these reasons, it was decided that the site should be addressed as part of a longer-term reforestation strategy and no short-term 
measures were proposed. Conversely, it should be noted that the north-facing slope A would probably recover from the fire relatively quickly with natural reforestation, so it would not necessarily require long-term restoration measures.

\section{Slope sections C and D (Val de Gilly)}

Sediment concentrations reaching the main channel were high for the stream draining these sections (Figure 9), despite relatively thin stony soils (Figure 6) on much of the mainly south-facing slope. The upper part of the slope section is accessible by a paved road as far as Val Daubert. Much of the slope is cut along the contours by paths and two narrow unmade roads, but these are inaccessible by most vehicles. The lower slope is inaccessible. The abundance of pine and mixed pine and oak stands in the middle and upper part of section $\mathrm{C}$ makes this an ideal location for LEBs on the slopes and LDDs in the tributary channels. The lower channel is too far from the stands and too inaccessible to be treated. The poor soil conditions (Figure 6) and southern aspect of both sections make it unlikely that a grass strip would survive, and it would probably have little impact on infiltration in the thin soils. Therefore, protection of slope section $\mathrm{D}$ is not possible in the short term, and it should be looked at more closely in a long-term reforestation strategy.

\section{Slope section E (Tourré)}

Fire severity (Figure 4) on this south-facing slope section was lower than the preceding sections and this is supported by the low sediment concentrations measured during the storm (Figure 9). Natural revegetation should proceed relatively quickly, and no vegetative measures were recommended.

\section{Slope section F (Périer)}

The upper slope of this section was severely burned (Figure 4) and is likely to be an area that generates considerable runoff and erosion. However, the main channel could not be accessed during the storm in the same conditions as for the other tributaries, so no suspended sediment data are available to support this. The slope is burned entirely on the mid- and upper portions, but there is a flat, densely vegetated strip between the channel of the Périer and the base of the burned slope. Although erosion rates will probably be high on this slope and it is accessible, there are no pine stands and the soils are thin and stony (Figure 6), so the site is not adapted to grass filter strips. In addition, runoff and sediments must be transported through the densely vegetated plain and through several kilometres of channel flow in the Périer before entering the main Giscle channel, so the site was deemed more appropriate for a long-term vegetative strategy.

\section{Assessment}

Many of the recommendations resulting from the study were adopted by the local municipalities. The major exception was the grass filter strip (section A) which was never sown. This was due essentially to lack of funding and poor timing. In addition, the sowing of grasses in the forest was not approved of by local forestry experts who felt the introduction of grasses was a form of ecological pollution that should be avoided. It appears, however, that over a period of four years or more, the native vegetation becomes dominant and only traces of the seeded species remain (Vallejo and Alloza, 1998; Fernandez-Abascal et al., 2003). The impact of sown grasses on natural revegetation was discussed above, and although sowing grasses in protective strips as suggested here would probably have no significant impact on natural regeneration over a period of a few years, this issue needs to be addressed more systematically in order to convince land managers that grass strips can contribute to reducing erosion at a reasonable cost and with low ecological risk.

In section A, 20 LDDs were installed in the two ephemeral streams draining the slope: 13 were put in a first stream and seven in another, and these were spaced at about 25-30 m intervals. It required eight days for two men to install the LDDs, but this included the clearing of the stream channel of debris and the cutting and stacking of all trees over a width of $3 \mathrm{~m}$ on either side of the channel over a total length of about $500 \mathrm{~m}$.

At the time of writing, a year has passed since the erosion control measures were installed and a study of their effectiveness in trapping sediments is underway. Initial observations suggest that the LDDs trap sediments in the sandsized fraction up to a depth of about $50 \mathrm{~cm}$. Finer sediments are transported into the main channel and gravel-sized sediments are absent from the structures and therefore were never detached and transported from the slopes during the initial events after the fire. Although no grainsize data are available for sediments dredged from the port downstream, 
the local authorities cite sand as the major problem, so LDDs appear to be appropriate structures for post-fire erosion control in this area. The study underway should determine the proportion of eroded sediments trapped and quantify the grain size distributions of both eroded and trapped sediments more precisely.

Not all the LEBs were installed as recommended: funding and available time set limits on the number of sites that could be treated, so the LEBs were put in place only in section C. These were of two types: (1) clearcutting all standing trees and laying trunks across the bare soil; and (2) cutting only the trees necessary for the LEBs and leaving the other charred trunks standing. In the first case, all pine trees within falling distance of electrical wires along the roadway were clearcut and systematically laid to protect the road from sediment deposition. Observations one year after their installation showed that sand- and gravel-sized sediments had accumulated behind the logs but the quantity retained was not estimated.

Sections B and D were identified by the erosion risk map as high risk areas, but no vegetation methods were suitable. Two other approaches could be used for these: the first is based on civil engineering techniques, and stone sediment dams were installed in the river channels. The other is long-term reforestation. Sections B and D are southfacing and have thinner soils and lower available soil moisture conditions than north-facing slopes. Vegetation regrowth is slower on these slopes and they are more likely to burn again due to drier conditions, so planting strategies should take these factors into consideration.

\section{Conclusions}

Major forest fires in the Mediterranean environment occur regularly and might become more frequent in the future as the climate changes. It is therefore necessary to elaborate strategies to limit runoff and soil erosion after a fire in order to minimize their impact. The method described above uses both live and dead vegetation to reduce runoff on slopes and trap sediments in streams. The main short-term live vegetation method consists of planting grass strips, but the introduction of grass species in the forest is viewed by some as undesirable. Short-term dead vegetation methods include both LDDs, which trap sediments in ephemeral streams, and LEBs, which maintain them on the slope. The cost-efficiency of these methods must now be analysed.

The method for choosing appropriate sites for these erosion control measures is based firstly on an assessment of the spatial distribution of erosion risk, and secondly on the evaluation of potential sites according to the impact on the main channel, soil resource to be protected, availability of suitable standing trees, and accessibility. It should be noted that although the soil erosion risk map produced in the first stage of the method is useful in identifying high risk areas, it does not represent in itself a sufficient tool for developing a soil conservation strategy. In the future, soil erosion modelling should be accompanied by the development of soil conservation models where high risk sites are evaluated for suitability to different erosion control methods.

\section{References}

Andreu V, Imeson AC, Rubio JL. 2001. Temporal changes in soil aggregates and water erosion after a wildfire in a Mediterranean pine forest. Catena 44: 69-84.

Barberis A, Dettori S, Filigheddu MR. 2003. Management problems in Mediterranean cork oak forests: post-fire recovery. Journal of Arid Environments 54: 565-569.

Cerdà A, Imeson AC, Calvo A. 1995. Fire and aspect induced differences on the erodibility and hydrology of soils at La Costera, Valencia, south-east Spain. Catena 24: 289-304.

DeBano LF. 2000a. Water repellency in soils: a historical overview. Journal of Hydrology 231-231: 4-32.

DeBano LF. 2000b. The role of fire and soil heating on water repellency in wildland environments: a review. Journal of Hydrology 231-231: 195-206.

Deletic A. 2001. Modelling of water and sediment transport over grassed areas. Journal of Hydrology 248: 168-182.

De Luis M, Gonzalez-Hidalgo JC, Raventos J. 2003. Effects of fire and torrential rainfall on erosion in a Mediterranean gorse community. Land Degradation and Development 14: 203-213.

Doerr SH, Shakesby RA, Walsh RPD. 1998. Spatial variability of soil hydrophobicity in fire-prone eucalyptus and pine forests, Portugal. Soil Science 163: 313-323.

Doerr SH, Shakesby RA, Walsh RPD. 2000. Soil water repellency: its causes, characteristics and hydro-geomorphological significance. Earth-Science Reviews 51: 33-65.

Espelta JM, Retana J, Habrouk A. 2003. An economic and ecological multi-criteria evaluation of reforestation methods to recover burned Pinus nigra forests in NE Spain. Forest Ecology and Management 180: 185-198.

Fernandez-Abascal I, Tarrega R, Luis-Calabuig E, Marcos E. 2003. Effects of sowing native herbaceous species on the post-fire recovery in a heathland. Acta Oecologica 24: 131-138. 
Ferreira AJD, Coelho COA, Shakesby RA, Walsh RPD. 1997. Sediment and solute yield in forest ecosystems affected by fire and ripploughing techniques, central Portugal: a plot and catchment analysis approach. Phyical Chemistry of the Earth 22: 309-314.

Gagari P, Lyrintzis G, Baloutsos G, Xanthopoulos G. 2001. Contribution of log erosion barriers to soil protection and vegetation recovery after wildfire in a Pinus halepensis forest, in Greece. In Proceedings of the International Conference, Forest Research: a Challenge for an Integrated European Approach, Thessaloniki, Greece, Radoglou K (ed.). 1: 311-316.

Giovannini G, Vallejo R, Lucchesi S, Bautista S, Ciompi S, Llovet J. 2001. Effects of land use and eventual fire and soil erodibility in dry Mediterranean conditions. Forest Ecology and Management 147: 15-23.

Hayes JC, Barfield BJ, Barnhisel RI. 1984. Performance of grass filters under laboratory and field conditions. Transactions of the American Society of Agricultural Engineers 27: 1321-1331.

Huffman EL, MacDonald LH, Stednick JD. 2001. Strength and persistence of fire-induced soil hydrophobicity under ponderosa and lodgepole pine, Colorado front range. Hydrological Processes 15: 2877-2892.

Imeson AC, Verstraten JM, van Mulligen EJ, Sevink J. 1992. The effects of fire and water repellency on infiltration and runoff under Mediterranean type forest. Catena 19: 345-361.

Inbar M, Tamir M, Wittenberg L. 1998. Runoff and erosion processes after a forest fire in Mount Carmel, a Mediterranean area. Geomorphology 24: $17-33$.

Le Bissonnais Y. 1996. Aggregate stability and assessment of soil crustability and erodibility: I. Theory and methodology. European Journal of Social Science 47: 425-437.

Letey J. 2001. Causes and consequences of fire-induced soil water repellency. Hydrological Processes 15: 2867-2875.

Ligdi E, Morgan RPC. 1995. Contour grass strips: a laboratory simulation of their role in soil erosion control. Soil Technology 8: $109-117$.

Marqués MA, Mora E. 1998. Effects on erosion of two post-fire management practices: clear-cutting versus non-intervention. Soil and Tillage Research 45: 433-439.

Martin C, Chevalier Y, Gimenez H, Quillard J. 1998. Variations de la composition chimique des eaux de drainage et de ruissellement et modifications des caractères agronomiques des sols après incendie de forêt dans le bassin versant du Rimbaud (Var, France). Géomorphologie 3: $215-232$.

Mataix-Solera J, Doerr SH. 2004. Hydrophobicity and aggregate stability in calcareous topsoils from fire-affected pine forests in southeastern Spain. Geoderma 118: 77-88.

Munoz-Carpena R, Parsons JE, Gilliam JW. 1999. Modeling hydrology and sediment transport in vegetative filter strips. Journal of Hydrology 214: 111-129.

Neary DG, Klopatek CC, DeBano LF, Ffolliott PF. 1999. Fire effects on belowground sustainability: a review and synthesis. Forest Ecology and Management 122: 51-71.

Pausas JG. 1997. Resprouting of Quercus suber in NE Spain after fire. Journal of Vegetation Science 8: 703-706.

Pausas JG. 2004. Changes in fire and climate in the eastern Iberian peninsula (Mediterranean basin). Climatic Change 63: 337-350.

Pausas JG, Vallejo VR. 1999. The role of fire in European Mediterranean Ecosystems. In Remote Sensing of Large Wildfires in the European Mediterranean Basin, Chuvieco E (ed.). Springer-Verlag, Berlin; 3-16.

Pinaya I, Soto B, Arias M, Díaz-Fierros F. 2000. Revegetation of burnt areas: relative effectiveness of native and commercial seed mixtures. Land Degradation and Development 11: 93-98.

Prosser IP, Williams L. 1998. The effect of wildfire on runoff and erosion in native Eucalyptus forest. Hydrological Processes 12: $251-265$.

Robichaud P. 2004. Post-fire rehabilitation treatments: are we learning what works? Southwest hydrology. Watersheds on Fire 3: $20-21$.

Rubio JL, Forteza J, Andreu V, Cerni R. 1997. Soil profile characteristics influencing runoff and soil erosion after forest fire: a case study (Valencia, Spain). Soil Technology 11: 67-78.

Shakesby RA, Coelho COA, Ferreira AJD, Terry JP, Walsh RPD. 1993. Wildfire impacts on soil erosion and hydrology in wet Mediterranean forest, Portugal. International Journal of Wildland Fire 3: 95-110.

Shakesby RA, Boakes DJ, Coelho COA, Gonçalves AJB, Walsh RPD. 1994. Limiting soil loss after forest fire in Portugal: the influence of different post-fire timber clearing practices. In Proceedings of 2nd International Conference on Forest Fire Research II: 1161-1170.

Shakesby RA, Boakes DJ, Coelho COA, Gonçalves AJB, Walsh RPD. 1996. Limiting the soil degradational impacts of wildfire in pine and eucalyptus forests in Portugal. Applied Geography 16: 337-355.

Shakesby RA, Doerr SH, Walsh RPD. 2000. The erosional impact of soil hydrophobicity: current problems and future research directions. Journal of Hydrology 231-232: 178-191.

Soto B, Díaz-Fierros F. 1998. Runoff and soil erosion from areas of burnt scrub: comparison of experimental results with those predicted by the WEPP model. Catena 31: 257-270.

Soto B, Basanta R, Pérez R, Díaz-Fierros F. 1995. An experimental study of the influence of traditional slash-and-burn practices on soil erosion. Catena 24: 13-23.

Tadesse LD, Morgan RPC, 1996. Contour grass strips: a laboratory simulation of their role in erosion control using live grasses. Soil Technology 9: 83-89.

Thomas AD, Walsh RPD, Shakesby RA. 1999. Nutrient losses in eroded sediment after fire in eucalyptus and pine forests in the wet Mediterranean environment of northern Portugal. Catena 36: 283-302.

Thomas AD, Walsh RPD, Shakesby RA. 2000. Solutes in overland flow following fire in eucalyptus and pine forests, northern Portugal. Hydrological Processes 14: 971-985.

Vacca A, Loddo S, Ollesch G, Puddu R, Serra G, Tomasi D, Aru A. 2000. Measurement of runoff and soil erosion in three areas under different land use in Sardinia (Italy). Catena 40: 69-92.

Vallejo R, Alloza JA. 1998. The restoration of burned lands: the case of eastern Spain. Large Forest Fires 91-108. 
Vought LBM, Pinay G, Fuglsang A, Ruffinoni C. 1995. Structure and function of buffer strips from a water quality perspective in agricultural landscapes. Landscape and Urban Planning 31: 323-331.

Wallis MG, Horne DJ. 1992. Soil water repellency. In Advances in Soil Science, Vol. 20, Stewart BA (ed.). Springer: New York; $91-146$.

Walsh RPD, Coelho COA, Shakesby RA, Terry JP. 1992. Effects of land use management practices and fire on soil erosion and water quality in the Agueda river basin, Portugal. Geoökoplus III: 15-36.

Walsh RPD, Boakes DJ, Coelho COA, Ferreira AJD, Shakesby RA, Thomas AD. 1995. Post-fire land use and management and runoff responses to rainstorms in northern Portugal. In Geomorphology and Land Management in a Changing Environment, McGregor DFM, Thompson DA (eds). Wiley: Chichester; 283-308.

Wohlgemuth PM, Hubbert KR, Robichaud PR. 2001. The effects of log erosion barriers on post-fire hydrologic response and sediment yield in small forested watersheds, southern California. Hydrological Processes 15: 3053-3066. 